\title{
Impact of Income on Life Expectancy: A Challenge for the Pension Policy
}

\author{
Damian Walczak ${ }^{1, * \mathbb{D}}$, Jacek Wantoch-Rekowski ${ }^{2} \mathbb{D}$ and Robert Marczak ${ }^{3}$ \\ 1 Faculty of Economic Sciences and Management, Nicolaus Copernicus University in Torun, Gagarina 13A, \\ 87-100 Torun, Poland \\ 2 Faculty of Law and Administration, Nicolaus Copernicus University in Torun, Bojarskiego 3 , \\ 87-100 Toruń, Poland; rekowski@umk.pl \\ 3 Department of Social Insurance, Warsaw School of Economics, Aleja Niepodległości 162, \\ 02-554 Warszawa, Poland; rmarcz@sgh.waw.pl \\ * Correspondence: dwalczak@umk.pl
}

Citation: Walczak, Damian, Jacek Wantoch-Rekowski, and Robert Marczak. 2021. Impact of Income on Life Expectancy: A Challenge for the Pension Policy. Risks 9: 65.

https://doi.org/10.3390/risks9040065

Academic Editor: Jens Perch Nielsen

Received: 18 February 2021

Accepted: 31 March 2021

Published: 2 April 2021

Publisher's Note: MDPI stays neutral with regard to jurisdictional claims in published maps and institutional affiliations.

Copyright: (c) 2021 by the authors. Licensee MDPI, Basel, Switzerland. This article is an open access article distributed under the terms and conditions of the Creative Commons Attribution (CC BY) license (https:// creativecommons.org/licenses/by/ $4.0 /)$.

\begin{abstract}
The aim of this paper is to present life expectancy of both genders depending on their income and to determine the impact of a possible regularity on the state pension policy. The study was based on the income of pensioners in Poland (over 5 million people receiving old-age pension). The results obtained made it possible to formulate several important conclusions: the rich live longer; the impact of income on life expectancy is much stronger among men than women; and with age, income has less and less impact on life expectancy. Consequently, in the capital model that is in force in Poland, the state should take this fact into account in its pension policy when calculating the amount of the benefit.
\end{abstract}

Keywords: life expectancy; gender gap; welfare justice; mortality; pension policy

\section{Introduction}

Why do some people live longer than others? The search for the causes of this fact is not easy, but one of the factors on which it depends is the income gained during the period of professional activity (Kreiner et al. 2018) and afterwards (Kinge et al. 2019).

Limiting the factors to income would be too much of an oversimplification. Other factors may include air pollution; smoking; obesity (Allen et al. 2016); personal characteristicsfor example, genetic diseases (Albertsen et al. 1996); education, which also affects income (Ross et al. 2012); family situation; alcohol drinking; smoking; physical activity; social contacts, religion (Mackenbach et al. 2019; Headey et al. 2014); race; functional status (Keeler et al. 2010); health lifestyle; and, of course, the health system (Cockerham 1997).

Only scientific determination of the actual factors that influence people to live longer can possibly make a real impact on these factors and their specific inclusion in the social policy of the state, including the pension policy, which is an indispensable part of it (Ervasti and Kangas 1995). However, to date, research on microdata in this area is not extensive (Chetty et al. 2016; Blanpain 2016). However, using microdata Gavrilov and Gavrilova (2015) studied the factors which could predict agents' exceptional longevities. This study demonstrated also that both midlife and early-life conditions affect life expectancy with some gender specificity. Most of the publications presented above are based on aggregated data for the entire population. We have therefore decided to investigate the impact on mortality of one of the factors presented above, namely, income. Determining the relationship between income and life expectancy requires not only research over a long period but also an appropriate research methodology. Thus, we have examined this relationship based on data from the Social Insurance Institution (SII-institution operating Polish general pension system) (Zakład Ubezpieczeń Społecznych (ZUS)) in Poland in relation to data on all pensioners in 2013 (base data year) and 2018 (last available year). 
How does the income, which we are investigating, impact a life expectancy? Many arguments can be cited to prove the existence of such a relationship. Richer people have less stressful life, consume better food, lead healthier lifestyles, rest more, obtain better education, and benefit from better health care (Kaplan et al. 1996; Lei et al. 2017). Thus, income, not in a direct way but by influencing many aspects of life, significantly affects its length (Marmot 2002; Fritzell et al. 2004).

In addition, the income effect that is shown may be different depending on gender. Women live longer and are happier than men (Solé-Auró et al. 2018; Flandorfer and Fliegenschnee 2011). According to the Organisation for Economic Organisation for Economic Co-operation and Development (2019), life expectancy at birth for women is currently longer than for men by a few, in case of highly developed countries, to even a number of years (e.g., Russia and South Africa). However, to date, the impact of income differentiation on further life expectancy in terms of gender has not been finally determined. Fedotenkov and Derkachev (2019), for example, show that higher income increases life expectancy both for males and females; however, males' life expectancy is affected to a larger extent. The literature indicates that women could live longer because of men's lifestyles (Cockerham 1997). Women are also more robust at every age, and the influence of oxidative stress on ageing and disease is important (Austad 2006). However, it is essential to examine whether the differences in income increase (or possibly reduce) the differences in life expectancy between women and men.

This work verifies the following research hypotheses:

Hypothesis 1 (H1). Richer people live longer.

Hypothesis 2 (H2). Income disparities affect both genders differently in terms of life expectancy.

Hypothesis 3 (H3). The longer life expectancy of the rich needs to be taken into account in the pension policy of the state.

The aim of this study is to present the life expectancy of both genders depending on their income and to determine the impact of this possible regularity on the pension and health policy of the state. The need to examine the impact of wealth and life expectancy results from the potential existence in the pension system of an unintended (and unknown) redistribution from the poor to the rich (Hupfeld 2006).

Including this introduction, the article consists of six parts. In the next section, we explain how the amount of pension benefits depends on citizens' lifetime income. Then, in the section entitled "Methodology", we describe how the data was obtained for the study, how it was arranged and how the analyzes were performed.

Then we present the results of analyzes of the relationship between the amount of income obtained after retirement and life expectancy in the context of the division into gender and the place of residence of pensioners. The penultimate section is devoted to the verification of the above hypotheses and indicates directions for changes in the Polish pension system in order to reduce the life expectancy discrepancy. The limitations of the analyzes undertaken are discussed in the last part of the article.

\section{Pension System in Poland: Impact of Salary/Activity on Pension}

The general pension system, operated by the SII, was substantially reformed on 1 January 1999 (for more, see Bińczycka-Majewska 2014). The key acts, i.e., the Social Insurance System Act of 13 October 1998 (Act 1998a) and the Social Insurance Fund Pensions and Disability Allowances Act of 17 December 1998 (Act 1998b), were intended to unify and consolidate pension issues. The reformers' intentions were only partially successful because there are many professional groups outside the insurance system-for example, judges, prosecutors, professional soldiers and officers of the Police, Internal Security Agency, Intelligence Agency, Military Counterintelligence Service, Military Intelligence Service, Central Anti-Corruption Bureau, Border Guard, State Protection Service, State 
Fire Service, Customs and Fiscal Service and Prison Service, and Customs Service. These entities do not pay contributions and their pension benefits within the supply system are financed from the state budget (the pension provision system). The direct payment of benefits is handled by numerous entities and varies for particular professional groups (e.g., Military Pension Office, Pension and Disability Office, individual courts, and prosecutor's offices). Additionally, outside the general system are farmers, who are covered by agricultural insurance with contributions which barely cover the expenses for agricultural pensions. In practice, agricultural pensions are financed from the state budget and their payment is handled by a different entity, namely, the Agricultural Social Insurance Fund (Wantoch-Rekowski 2005; Miceikiene et al. 2019).

Calculating pensions from the general system in Poland is complicated. To simplify this matter, it is reasonable to assume that until 31 December 1998, there was the "old" model, based on the defined-benefit system, and since 1 January 1999, there has been the "new" model, based on the defined-contribution system. The literature rightly points out that the pension system which was introduced on 1 January 1999 had to properly address the problem of the current and subsequent functioning of pension benefits for particular age groups. A gradual transition from the "old" to the "new" system was adopted, depending on the age of the insured person (Sowiński 2009). However, people of the same age, in both systems, subject to the same legal regulations, regardless of the retirement date.

Pension benefits under the old system depended on two elements: a fixed (social) part and an individual part, depending on years of insurance (the so-called contributory and non-contributory) and the so-called assessment basis. The assessment basis was directly related to the earnings of the person applying for the pension. It resulted from a comparison of the individual annual salary with the national average salary in a given year (Jedrasik-Jankowska 2003, 2010). The insured showed the amount of his or her earnings based on two choices:

(1) from 20 years selected freely from his or her professional activity,

(2) from 10 consecutive years of employment out of 20 years before retirement.

It should be stressed that the amount of earnings under the old system was not the only element used in the calculation of the benefit but was a significant part thereof. What is important is that the amount of earnings was not taken into account from the whole period of the insured's activity but from only the most beneficial part. However, considering that the insured's earnings were counted from 10 or 20 years of professional activity, it is generally justified to simplify that this solution reflected whole-life earnings to a large extent.

The new system introduced a solution in which the amount of the benefit (especially in relation to persons providing employment under an employment relationship) depends on the two factors. An amount of old-age pension insurance contributions recorded in the insured's account, paid by the insured and the employer is divided by further life expectancy (Kluszczyńska 2003). The old-age pension insurance contributions are collected as a percentage of the remuneration defined in the act; consequently, there is a direct relationship between the amount of earnings and the amount of contributions. In addition, the contributions are mostly revenue for the State Treasury - the fully funded pillar is currently voluntary-and are adjusted annually. Conversely, the life expectancy tables are unisex, i.e., independent of gender (and any other factor outside of age). The absence of gender-differentiated scoreboards affects the redistribution of income from shorterliving men to longer-living women, who are thus remunerated for maternal tasks (the arrangement benefits, of course, also women who have no children) (Steinhilber 2004).

The legislator took into account the fact that some of the insured persons were active for many years before 1 January 1999, in the old system. For those insured persons, a calculation of the so-called initial capital was provided for. The initial capital is the reconstituted amount of the old-age pension insurance contributions on remuneration before 1 January 1999. 
There is no doubt that the Polish general pension system makes the amount of the benefit less (old system) or more (new system) depending on the amount of earnings achieved by the insured during his or her lifelong professional activity.

The result is not affected by the pension valorization, which in Poland is percentage and annual and, secondly, the results presented in the study are relative, not absolute. So, percentage changes in the numbers used in the calculation do not change the results. In turn, the valorization of the accumulated contributions (accounts in SII) should ensure the real value of it and resilient to development of the amount of wages (SII 2019).

\section{Methodology}

For the purposes of the study, information on the amount of the pension benefits resulting from the age at the time of granting and the death of a pensioner was obtained from two IT systems: the Comprehensive IT System of the SII (the Polish abbreviation is KSI SII-the first system) and EMIR-SEKS/AD (the second system). The task of developing the data was commissioned to the Software Development Department of the SII headquarters in cooperation with the Research and Scientific Cooperation Section in the SII President Office. KSI SII was created by Prokom (a Polish IT company), implemented in 1999 together with the pension reform in Poland, and then developed by Asseco (a Polish IT company that has made a number of mergers and acquisitions in the Polish IT market). KSI SII currently consists of 39 interactive applications supporting the implementation of the SII tasks of employees and managers at various levels.

Since the implementation of the defined-contribution system in 1999, to determine benefits and undertake the immediate transfer of funds obtained from contributions to the current obligations of the system towards those who are entitled to receive social insurance benefits, the key is information on the contributions paid on the individual account of each insured. These data are administered by the SII.

The launching and functioning of the social insurance system, which operates in such an institutional and client environment and which requires constant information transfer, would not be possible without the modern IT support provided by KSI SII that currently supports 15.8 million active insured accounts, 7.7 million pensioners and disabled people (4.96 pensioners in 2013 and 5.62 pensioners in 2018), and 2.6 million contribution payers (data from 2018) (SII 2018).

Processing the received data the current monthly payment amounts were used to calculate the average monthly pension. Data on deceased persons were extracted based on the date of suspension of payment was made. The data summary was prepared based on the amount of the gross benefit granted and the date of death in the part regarding the deceased. Statistical information was obtained from 43 local SII branches (SII branches are only partially territorially connected with Polish administrative districts) and then added up.

It should be emphasized that the data obtained related to all the records of the beneficiaries' database and not to a randomly selected representative sample, which means that the survey covered the entire population of pensioners in the Polish pension system. In connection with the annual indexation of old-age pensions as well as cases of overpaid pensions after the death of the beneficiary (due to the institution's periodic lack of knowledge of this fact), the data contained in the system are subject to slight changes but should not have a significant impact on the main conclusions of the presented analysis.

In this study, data related to most of the pensioners receiving benefits from the SII (Table 1) were analyzed (the data is publicly available upon request). Taking into account the rounding up or down of the generally available data of the persons receiving pensions (earlier part of the work), it can be assumed that $100 \%$ of the beneficiaries were examined. Therefore, the study presented in this paper fully reflects the situation concerning the life expectancy of an increasing number of pensioners in the general system in Poland. 
Table 1. Number of people included in the study.

\begin{tabular}{ccccc}
\hline \multirow{2}{*}{ Specification } & \multicolumn{2}{c}{2013} & \multicolumn{2}{c}{2018} \\
\cline { 2 - 5 } & Women & Men & Women & Men \\
\hline Number of pensioners (average) & $2,871,692$ & $2,005,068$ & $3,417,118$ & $2,286,964$ \\
Number of deceased persons & 67,790 & 81,786 & 89,586 & 102,212 \\
\hline Source: authors' own study & (KSI SII. EMIR-SEKS/AD) &
\end{tabular}

Source: authors' own study based on both systems (KSI SII; EMIR-SEKS/AD).

The research does not include survivors' pensions (pensions granted for widows and widowers). In Poland, by SII, survivors' pension is classified as a disability benefit (not a pension), so the results interpretation is not disturbed by it.

In our study, we first calculated the average pension received from the SII, dividing the sum of payments in particular months by the number of pensioners. Second, we calculated the average pension received only by pensioners who died in a specific year, dividing the sum of the pension payments in specific months by the number of deceased persons. In order to make the data comparable, we used the amount of the pension in the month preceding the death. This decision was necessary because the SII pension benefits are paid out on several dates; therefore, in some cases, the pension in the month of death was not paid out. These amounts were then deducted from each other. To receive relative difference, the result was divided by the average pension received only by pensioners who died. In this way, a result was obtained, making it possible to determine the appropriate ratio, defined by us as the "Income and life expectancy ratio". This ratio actually measures impact of the income on life expectancy, because we can compare the amount of benefits of the deceased persons with the amount of benefits of all pensioners. The same method of analysis described above was applied to both periods: 2013 and 2018.

$$
\bar{X}=\frac{\left(\sum P\right) /\left(\sum N\right)-\left(\sum P_{d}\right) / \sum n_{d}}{\left(\sum P_{d}\right) /\left(\sum n_{d}\right)} \times 100
$$

$P$-amount of all benefits paid out in particular months;

$N$-number of all pensioners in each month;

$P_{d}$-amount of deceased persons' benefits (in the month preceding death);

$n_{d}$-number of deceased pensioners in each month.

\section{Results}

In studies from both sources (all country and for SII branches) presented in this paper regarding the impact of income on life expectancy depending on age and the impact of income on life expectancy depending on place of residence, the indicated calculations based on formula 1. In both cases, separate studies were conducted for individual gender.

We will begin by analyzing the impact of income on life expectancy, taking age into account. The positive value in the table, which occurs more frequently, means that in a given year among a given age category, the average value of the pension for all persons receiving it is higher than the average value of the pension for the deceased. This, in our opinion, indicates that poorer people are dying earlier. Taking into account the methods indicated in the paper for calculating the pension benefit, these are poorer people not only during the retirement period but also during their entire lives, which influenced the amount of the pension benefit.

There is a noticeable decrease in the difference between the average amount of all the pensions and those of the deceased as the age of the pensioners' increases (Table 2). This relationship may indicate that the impact of income on life expectancy is decreasing. It could mean also that only the strongest have survived, but it is correlated, as mentioned, with income and wealth. 
Table 2. Income and life expectancy ratio by age (in \%).

\begin{tabular}{|c|c|c|c|c|}
\hline \multirow[b]{2}{*}{ Age } & \multicolumn{2}{|c|}{2013} & \multicolumn{2}{|c|}{2018} \\
\hline & Women & Men & Women & Men \\
\hline$<65$ & 12.0 & 16.8 & 13.5 & 18.0 \\
\hline 65 & 2.7 & 6.3 & 7.8 & 6.2 \\
\hline 66 & 4.7 & 9.8 & 5.6 & 5.5 \\
\hline 67 & 1.9 & 9.0 & 3.7 & 4.3 \\
\hline 68 & 2.0 & 8.4 & 5.4 & 4.7 \\
\hline 69 & 2.3 & 5.2 & 2.6 & 4.5 \\
\hline 70 & 1.1 & 5.9 & 4.2 & 4.9 \\
\hline 71 & 2.7 & 7.0 & 3.6 & 4.7 \\
\hline 72 & 1.7 & 5.1 & 3.5 & 4.8 \\
\hline 73 & 0.7 & 4.4 & 2.0 & 3.3 \\
\hline 74 & 2.0 & 5.1 & 0.3 & 5.9 \\
\hline 75 & 0.9 & 5.6 & 1.3 & 3.2 \\
\hline 76 & 1.8 & 4.1 & -0.7 & 3.3 \\
\hline 77 & 1.6 & 4.6 & -0.1 & 2.1 \\
\hline 78 & 0.7 & 4.5 & -0.1 & 3.3 \\
\hline 79 & -0.4 & 4.4 & -0.4 & 3.3 \\
\hline 80 & 1.3 & 3.2 & -2.5 & 1.3 \\
\hline$>80$ & 0.1 & 6.1 & -0.9 & 2.5 \\
\hline Average & 6.1 & 12.7 & -0.6 & 8.7 \\
\hline
\end{tabular}

Source: authors' own study.

Moreover, in several cases, for 2018 and only for the oldest women, there is no confirmation of the impact of income on life expectancy. It should be emphasized that in several discussed cases, the average pension of women who died was higher than the average pension (by only a few zlotys). However, this apparent discrepancy is an important scientific conclusion. Poorer people-in this case women-actually live for so much shorter a period that in the case of people over 75 years of age and this assumption has already been fully realized; therefore, for the oldest people, the above assumption no longer works. Additionally, mainly for women over 75 but also for men, other factors are more important than the amount of the pension. According to earlier studies, the health status of the elderly - to a lesser extent applicable to younger people-may also be one of these factors, because e.g., people with a poor functional status have a high annual mortality (Keeler et al. 2010).

When analyzing the differences between the average pension of all persons and the average pension of the deceased depending on the place of residence, the relevant dependencies can also be indicated (Table 3, Figure 1). In the case of men, generally in all branches in Poland (except for two branches in 2018 and one in 2013), those who die earlier receive lower pensions. In the case of women, the differences are more noticeable. In a few (in 2013) or a dozen or so branches (2018) in Poland, the pattern concerning the shorter lives of female pensioners receiving lower benefits that is presented in this paper is not confirmed. Most of the presented branches are located in the south of Poland and mostly in Silesia (Opała 2015), which is the area with very unfavorable and indeed some of the worst climatic conditions in Europe as a result of environmental pollution by using coal and burning "anything" in furnaces (EEA European Environment Agency). 
Table 3. Income and life expectancy ratio by Social Insurance Institution (SII) branches (in \%).

\begin{tabular}{|c|c|c|c|c|}
\hline \multirow{2}{*}{$\begin{array}{ll}\text { SII Branches } & \text { Year } \\
\end{array}$} & \multicolumn{2}{|c|}{2013} & \multicolumn{2}{|c|}{2018} \\
\hline & Women & Men & Women & Men \\
\hline Lublin & 13.8 & 21.7 & 15.8 & 27.2 \\
\hline Bialystok & 14.1 & 14.8 & 15.3 & 17.4 \\
\hline Bilgoraj & 17.7 & 19.0 & 18.9 & 13.1 \\
\hline Bydgoszcz & 12.0 & 10.1 & 15.6 & 10.1 \\
\hline Poznan (I branch office) & 13.8 & 5.0 & 9.3 & 6.2 \\
\hline Poznan (II branch office) & 18.7 & 21.8 & 9.4 & 19.7 \\
\hline Pila & 11.3 & 7.4 & 18.2 & 3.6 \\
\hline Gorzow Wielkopolski & 18.2 & 10.5 & 11.4 & 12.9 \\
\hline Koszalin & 16.7 & 7.9 & 7.7 & 12.9 \\
\hline Jaslo & 16.7 & 9.3 & 3.2 & 1.1 \\
\hline Olsztyn & 21.5 & 16.1 & 16.5 & 11.6 \\
\hline Ostrow Wielkopolski & 10.7 & 11.0 & 8.2 & 7.1 \\
\hline Lodz (I branch office) & 11.5 & 10.6 & 2.2 & 2.8 \\
\hline Lodz (II branch office) & 9.6 & 16.8 & 1.7 & 7.4 \\
\hline Opole & 15.6 & 14.7 & 7.9 & 11.7 \\
\hline Plock & 34.2 & 21.6 & 7.9 & 14.6 \\
\hline Radom & 10.4 & 8.2 & 7.4 & 11.1 \\
\hline Rzeszow & 10.0 & 14.9 & 8.3 & 7.8 \\
\hline Siedlce & 15.9 & 18.0 & 4.9 & 2.0 \\
\hline Slupsk & 7.1 & 14.2 & 1.6 & 9.1 \\
\hline Warszawa (I branch office) & 10.2 & 7.1 & 6.7 & 9.7 \\
\hline Warszawa (II branch office) & 12.2 & 10.0 & 13.6 & 2.2 \\
\hline Warszawa (III branch office) & 16.8 & 11.6 & 4.7 & 9.7 \\
\hline Tomaszow Mazowiecki & 10.2 & 14.4 & 7.6 & 7.0 \\
\hline Wroclaw & 6.4 & 7.1 & 6.1 & 9.2 \\
\hline Legnica & 13.6 & 25.0 & 0.6 & 30.6 \\
\hline Torun & 8.8 & 9.2 & 10.7 & 7.2 \\
\hline Elblag & 12.6 & 8.3 & 9.1 & 12.2 \\
\hline Gdansk & 15.0 & 10.4 & 14.2 & 11.9 \\
\hline Szczecin & 17.4 & 18.9 & 16.0 & 11.7 \\
\hline Kielce & 8.5 & 8.2 & -0.5 & 4.7 \\
\hline Zielona Gora & -0.6 & 11.6 & -4.1 & 14.6 \\
\hline Walbrzych & 11.5 & 12.7 & -5.1 & 13.1 \\
\hline Nowy Sacz & 1.9 & -4.2 & -7.4 & -10.4 \\
\hline Rybnik & -8.8 & 18.8 & -32.4 & 21.1 \\
\hline Sosnowiec & -5.3 & 6.3 & -22.6 & 13.9 \\
\hline Zabrze & 1.4 & 12.5 & -9.4 & 17.6 \\
\hline Tarnow & 9.1 & 1.8 & -17.6 & -7.3 \\
\hline Krakow & -0.6 & 9.1 & -8.7 & 2.1 \\
\hline Chrzanow & -5.9 & 17.5 & -22.4 & 21.8 \\
\hline Czestochowa & 3.5 & 9.1 & -9.4 & 12.6 \\
\hline Chorzow & -1.7 & 14.5 & -10.1 & 11.4 \\
\hline Bielsko-Biala & 1.9 & 15.0 & -8.3 & 24.4 \\
\hline
\end{tabular}

Source: authors' own study.

According to the studies that have been carried out, air pollution can negatively affect life expectancy (Brunekreef 1997; Pope et al. 2009). In this case, it is likely that the influence of this important factor on health and life expectancy resulted in the weakening or lack of the relationship indicated in the study (mainly branches 1-10 on the Figure 2). This is probably caused by the fact that compared to income, the environment could have a more significant impact on life expectancy (Allen et al. 2016); however, this conclusion remains outside the scope of this study. 

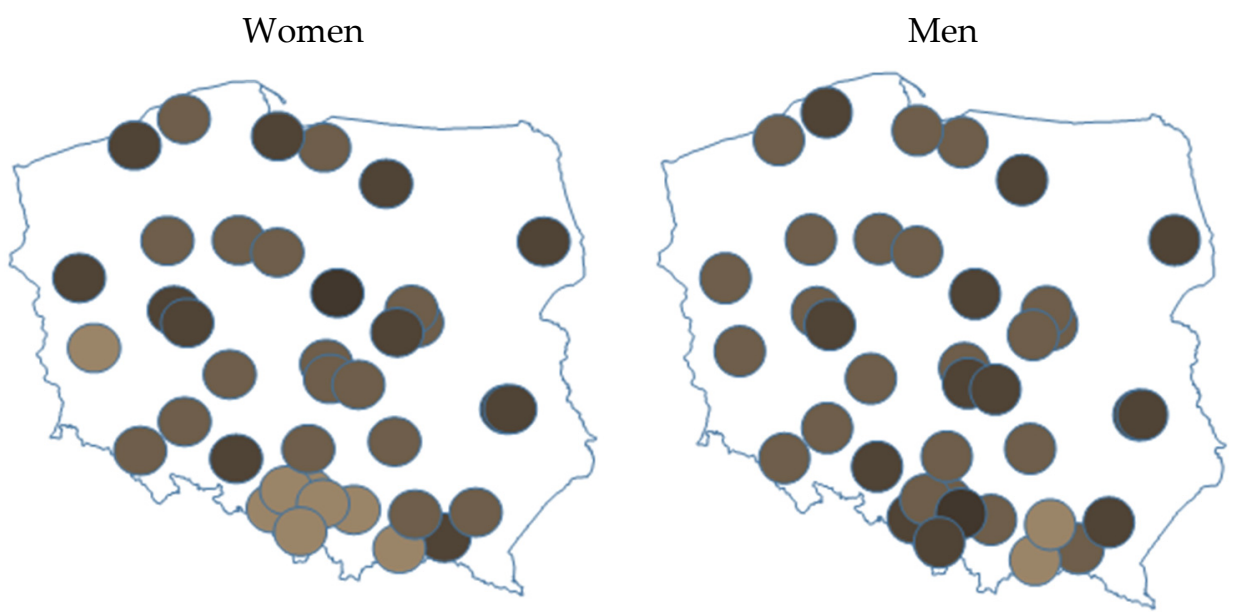

2018
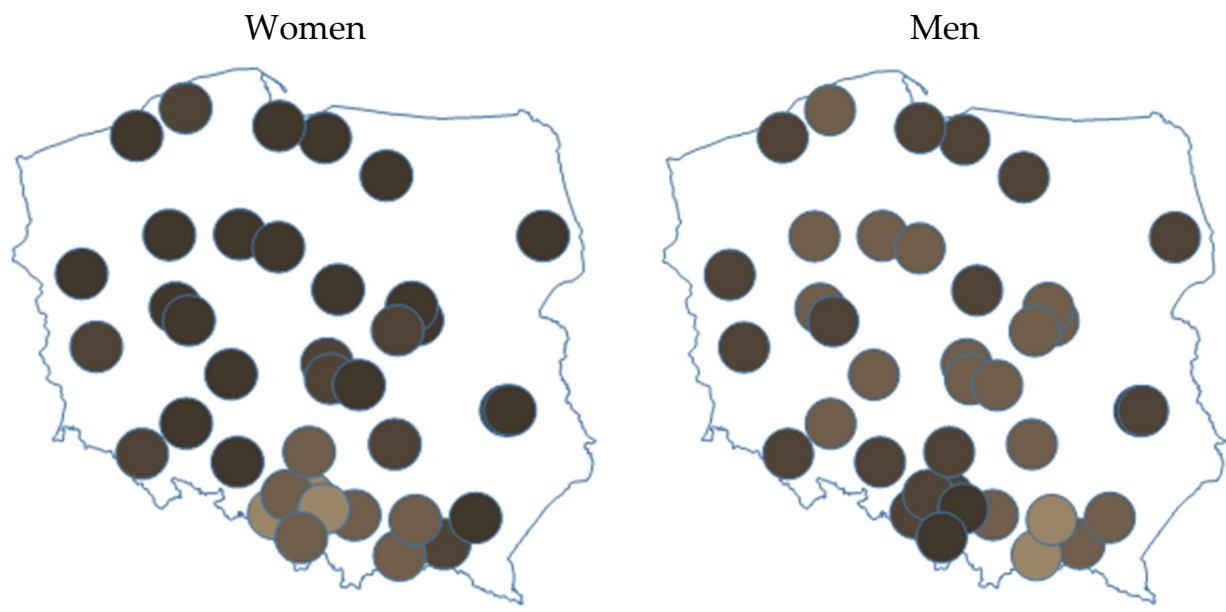

Figure 1. Geographical differentiation of the relationship between income and life expectancy in Poland. Source: authors' own study (using CONT-EVO MAP).

Figure 1 presents the geographical differentiation of the values presented in Table 3. In each of the figures we used 4 shades, the lightest for the smallest values, and the darkest for the largest values.

We also create the figure (Figure 2) which presents "Income and life expectancy ratio" in every branch-the results are ordered according to increasing ratio for women in 2013 and the numbers of branches in 2013 and 2018 are fixed (the horizontal axis present the number of the SII branches). As mentioned, We can observe strong geographical differentiation and values for men are higher than for women and reasonably stable (for women 2013 and women 2018 The Pearson correlation coefficient $=0.773 ; p=0.000$; for men 2013 and men 2018 The Pearson correlation coefficient $=0.711 ; p=0.000$ ). 


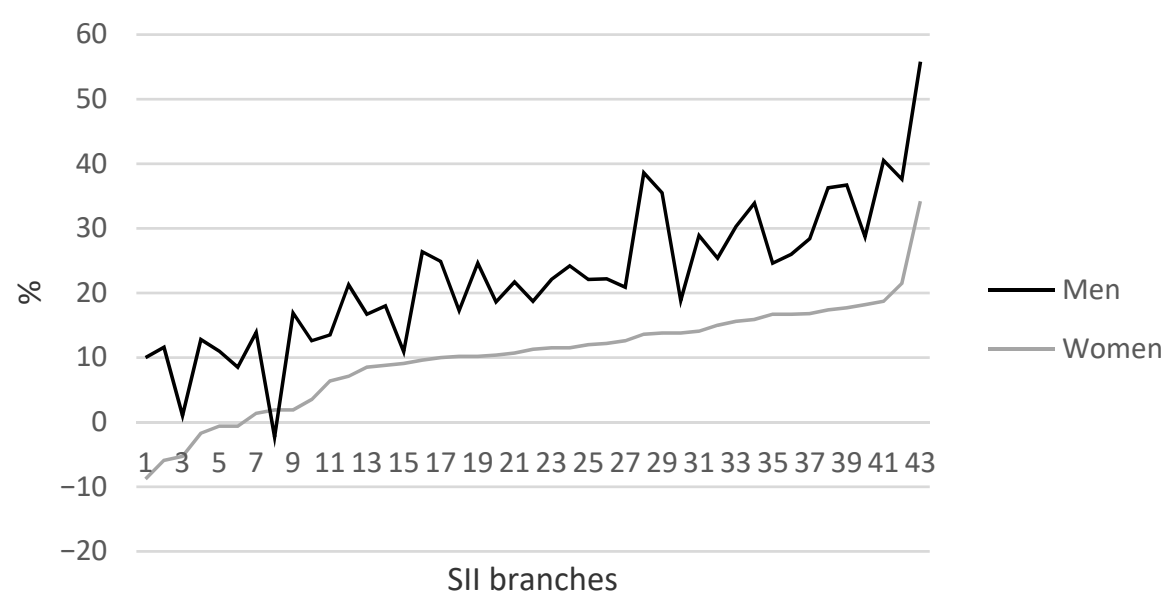

2018

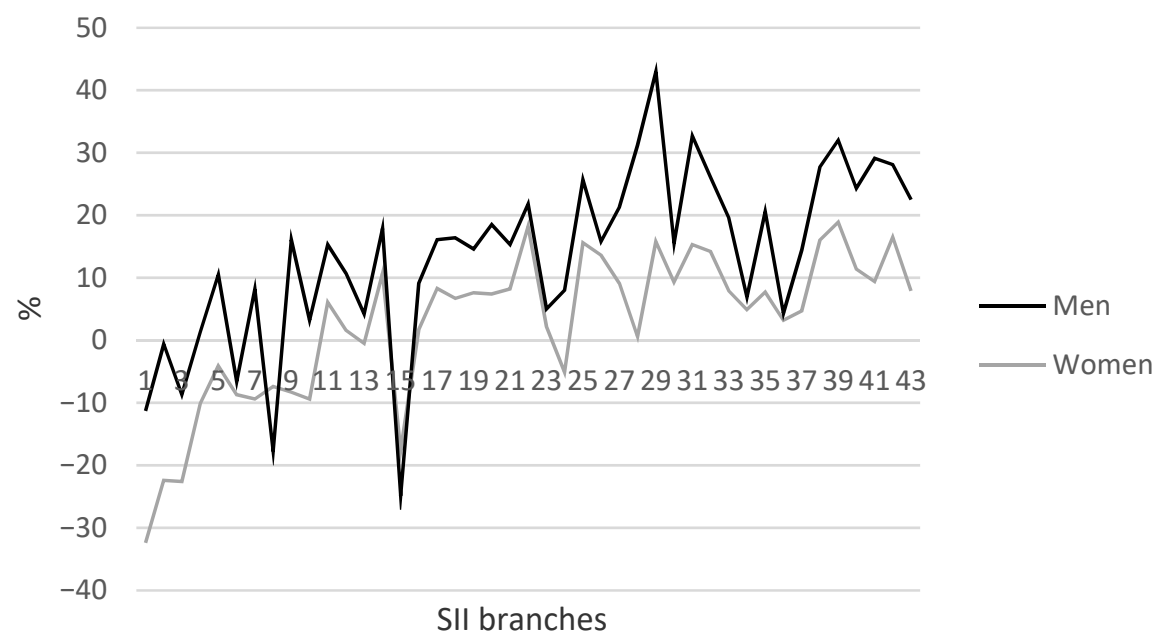

Figure 2. Income and life expectancy ratio in 43 SII branches (in \%). Source: authors' own study.

\section{Discussion and Conclusions}

We have demonstrated that richer people live longer. The impact of income on life expectancy is much stronger among men than among women. For women, life expectancy is strongly influenced by other factors. Among women, mainly in the so-called Upper Silesia, there is even a lack of connection between income and life expectancy. This is a highly industrialized area; therefore, women are probably more likely to feel the negative impact of environmental pollution on their health. These results indicate that not only income (Chapman and Hariharan 1996) but also gender in the context of income are important factors influencing further life expectancy. In this context, it should be stressed that the average difference between the pensions of deceased persons and all persons decreases with age. According to research, there is even a reversal of the situation for women after 75 years of age, as the average pensions of the deceased were higher than the overall average pension. This is probably the result of an earlier finding: the richer live longer, while the poorer live for a shorter period, and this fact is mainly observed in the years immediately following retirement. The above conclusions allow us to confirm the first two hypotheses presented in the study-that is, the amount of income and pension is a strong correlate of life expectancy and is different for both genders.

By analyzing our results, we want to emphasize that people who have poor health (drink alcohol, use drugs, or eat unhealthily) may work less and receive lower pensions, so they can live shorter. However, poor health caused by it can apply to both genders in a similar way. Furthermore, Fedotenkov and Derkachev (2019) showed that more work 
reduces life expectancy. But, according to our study, more work means higher pension and for men it probably could balance the negative effects of work on health and life expectancy.

Moreover, the conclusions that have been formulated go far beyond the hypotheses and research intentions set out in this paper. We planned to examine only the impact of income and gender on life expectancy; however, we have in addition arrived at the following two conclusions:

(1) As we grow older, income has less and less impact on life expectancy,

(2) The impact of income on life expectancy can be affected by other factors (e.g., in our research, or by air pollution).

If we want smaller differences in life expectancy values, large disparities in citizens' income should be avoided. Avoidance of large disparities is therefore a direct recommendation and in principle partly self-financing. In a society with smaller income disparities, people live longer and more healthily (e.g., Cockerham 1997); thus, they can work longer and retire later in life if they want to, and they fall ill less often. Unfortunately, some people might consider this recommendation inappropriate; it is also not easy to implement. However, increasing the income of individuals is beneficial on both a micro and macro scale for financial and ethical reasons. In a system of defined-contributions, increasing income during the period of professional activity translates to increasing income during the period after this activity; therefore, the role of the state should be to encourage people to work and care for the development of the economy, which will provide better-paid jobs.

As we have indicated in the new pension system in Poland (but also in other countries), when calculating the amount of the pension benefit, the accumulated capital is divided by further life expectancy. The life expectancy tables that are common to all insured persons depend exclusively on the age at which the future beneficiary retires. They do not depend on gender, amount of accumulated capital, place of residence, nor amount of benefit. In the meantime, based on common life-expectancy tables, the rich live longer, and thus benefit financially at the expense of the poor. They receive benefits for a longer period; therefore, the amounts are not only higher because of the accumulated capital but are also higher in terms of the sum of the accumulated benefits that are paid out, because rich people receive these benefits for a longer period (Hupfeld 2009). The above statements confirm Hypothesis 3. In this case, there is an unintended horizontal redistribution from the poor to the rich. Poland, but this probably applies to most countries, should take this fact into account when constructing the pension and tax system and perhaps, or mainly, when making changes in the labor market; this would lead to the minimization of income inequalities among economically active people and pensioners. The knowledge of the scientific problem examined in the text will result in this redistribution still being unintentional but already known. A proper debate in the future will lead to a real pension-law discussion about the need to take into account the longer lives of the rich in the calculation of the benefit. As a result, a properly built pension system will ensure fair redistribution, and those who are likely to live longer will receive lower benefits (Stiglitz and Rosengard 2015). However, this may be difficult for political reasons, because the rich have more political influence than the poor and will probably prevent such changes (Corstange 2018; Ostry et al. 2014). But, according to Bucciol et al. (2017), it is also possible that the current pension systems, for example, in France and Sweden, redistribute the income from rich to poor. So, the changes should be comprehensive, deliberate and thoroughly vetted to ensure, above mentioned, fair redistribution.

Pursuant to the current Polish regulations, the only instrument for limiting the amount of pension is the application of the "thirty-fold" principle, according to which the annual basis for calculation contributions to retirement and disability insurance in a given calendar year may not exceed the amount corresponding to thirty times the forecast average monthly salary in the national economy for a given calendar year (Gudowska and StrusinskaZukowska 2011). It must be admitted, however, that it is of marginal importance for smoothing out the differences in the amount of pensions in the context of the amount of the spread of earnings during the professional career. 
The conclusion from the text concerning the significant level of correlation between life expectancy and income, and consequently the level of the pensions dependent on income, is a challenge for social policy towards the elderly. In the absence of effective measures to eliminate the identified income inequalities in the labor market and the impossibility of flattening them in the form of vertical redistribution (Nelissen 1995), the need for an indexation of old age is even more important. It should consist of changes in social awareness and the reorganization of social life (Rysz-Kowalczyk and Szatur-Jaworska 2004). Its aim should be non-financial activities on the part of the state within the framework of social policy, i.e., assistance in adjusting the activity of each person to his or her abilities at the end of his or her life and enabling a peaceful retirement (Tobiasz-Adamczyk 2000). Actions should also be geared towards making individuals feel that they are part of the society and community until the end of their lives (Auleytner 2005).

\section{Limitations of This Study}

This article does not present the factors that may influence the longer life expectancy of rich people. The impact of income was examined without analyzing how it affects mortality and what actually causes the longer life expectancy of rich people.

Moreover, this article is based on the income of individual pensioners and does not present the income of their households. First, this income may also have an impact on the life expectancy of household members. Second, the incomes of the individual pensioners presented in the study may differ significantly from the incomes of their entire households.

The data presented in the article are based on the SII-the general pension system in Poland. The article does not examine the impact of income on life expectancy for pensioners from the pension provision system (uniformed services, judges, and prosecutors) and the agricultural system. At the same time, because the benefits in both of those systems are calculated on the basis of the so-called defined-benefit method, it would not be possible to determine the relationship between income and life expectancy.

We do not use-for example-the regression methods to determine the statistical significance of the results. However, in the paper we have decided to calculate the relative difference of pension benefits between the two groups in 2 years for each age (Table 2) and for each SII branch (Table 3; Figures 1 and 2). The comparative analysis of these two different periods allowed us to describe and perceive the same phenomenon and to present further conclusions.

Author Contributions: Conceptualization, D.W., J.W.-R., and R.M.; methodology, D.W. and R.M.; formal analysis, J.W.-R.; resources, R.M.; data curation, D.W. and R.M.; writing-original draft preparation, D.W., J.W.-R., and R.M.; writing-review and editing, D.W., J.W.-R., and R.M.; visualization, D.W. All authors have read and agreed to the published version of the manuscript.

Funding: The authors did not receive support from any organization for the submitted paper and The APC was funded by Nicolaus Copernicus University in Torun.

Institutional Review Board Statement: Not applicable.

Informed Consent Statement: Not applicable.

Data Availability Statement: Data available on request due to restrictions. The data presented in this study are available on request from the SII.

Acknowledgments: Not applicable.

Conflicts of Interest: We declare that there is no conflict of interest.

\section{References}

Act. 1998a. Act of 13 October 1998 on the Social Insurance System. Journal of Laws 137: 887.

Act. 1998b. Act of 13 December 1998 on the Social Insurance Fund Pensions and Disability Allowances. Journal of Laws $162: 1118$.

Albertsen, J. Peter C., Dennis G. Fryback, Barry E. Storer, Thomas F. Kolon, and Judith Fine. 1996. The Impact of Co-Morbidity on Life Expectancy among Men with Localized Prostate Cancer. The Journal of urology 156: 127-30. [CrossRef] 
Allen, Ryan T., Nicholas M. Hales, Andrea Baccarelli, Michael Jerrett, Majid Ezzati, Douglas W. Dockery, and C. Arden Pope III. 2016. Countervailing Effects of Income, Air Pollution, Smoking, and Obesity on Aging and Life Expectancy: Population-Based Study of US Counties. Environmental Health 15: 1-9. [CrossRef]

Auleytner, Julian M. 2005. Polska Polityka Społeczna (Polish Social Policy). Warszawa: WSP TWP.

Austad, Steven N. 2006. Why Women Live Longer than Men: Sex Differences in Longevity. Gender Medicine 3: 79-90. [CrossRef]

Bińczycka-Majewska, Teresa. 2014. Powszechność Systemu Ubezpieczeń Społecznych-Teoria i Praktyka (The Universality of the Social Insurance System-Theory and Practice). In Systemy Ubezpieczeń Społecznych-Między Solidaryzmem a Indywidualizmem (Social Insurance Systems-Between Solidarity and Individualism). Edited by Marian Żukowski. Warszawa-Lublin: PSUS.

Blanpain, Nathalie. 2016. Les Cadres Vivent Toujours 6 ans de Plus que les Ouvriers. Insee Première, 1584. Available online: https: / / www.insee.fr/fr/statistiques/1908110 (accessed on 10 January 2021).

Brunekreef, Bert. 1997. Air Pollution and Life Expectancy: Is There a Relation? Occupational and Environmental Medicine 54: 781. [CrossRef] [PubMed]

Bucciol, Alessandro, Laura Cavalli, Igor Fedotenkov, Paolo Pertile, Veronica Polin, Nicola Sartor, and Alessandro Sommacal. 2017. A large scale OLG model for the analysis of the redistributive effects of policy reforms. European Journal of Political Economy 48: 104-27. [CrossRef]

Chapman, Kenneth S., and Govind Hariharan. 1996. Do Poor People Have a Stronger Relationship between Income and Mortality than the Rich? Implications of Panel Data for Health-Health Analysis. Journal of Risk and Uncertainty 12: 51-63. [CrossRef]

Chetty, Raj, Michael Stepner, Sarah Abraham, Shelby Lin, Benjamin Scuderi, Nicholas Turner, Augustin Bergeron, and David Cutler. 2016. The Association between Income and Life Expectancy in the United States, 2001-2014. JAMA 315: 1750-66. [CrossRef] [PubMed]

Cockerham, William C. 1997. The Social Determinants of the Decline of Life Expectancy in Russia and Eastern Europe: A Lifestyle Explanation. Journal of Health and Social Behavior 38: 117-27. [CrossRef]

Corstange, Daniel. 2018. Clientelism in Competitive and Uncompetitive Elections. Comparative Political Studies 51: 76-104. [CrossRef]

EEA (European Environment Agency). 2018. Air Quality in Europe-2018 Report. Copenhagen: EEA.

Ervasti, Heikki, and Olli Kangas. 1995. Class Bases of Universal Social Policy: Pension Policy Attitudes in Finland 1993. European Journal of Political Research 27: 347-50. [CrossRef]

Fedotenkov, Igor, and Pavel Derkachev. 2019. Gender longevity gap and socioeconomic indicators in developed countries. International Journal of Social Economics 47: 127-44. [CrossRef]

Flandorfer, Priska, and Katrin Fliegenschnee. 2011. The gender gap in life expectancy in Austria: Theoretical considerations based on a qualitative grounded theory study. Journal of Public Health 19: 481-90. [CrossRef]

Fritzell, Johan, Magnus Nermo, and Olle Lundberg. 2004. The Impact of Income: Assessing the Relationship between Income and Health in Sweden. Scandinavian Journal of Public Health 32: 6-15. [CrossRef] [PubMed]

Gavrilov, Leonid A., and Natalia S. Gavrilova. 2015. Predictors of exceptional longevity: Effects of early-life and midlife conditions, and familial longevity. North American Actuarial Journal 19: 174-86. [CrossRef]

Gudowska, Beata, and Jolanta Strusińska-Żukowska. 2011. Ustawa o Systemie Ubezpieczeń Społecznych (Komentarz) (Act on the Social Insurance System. Commentary). Warsaw: C.H. BECK, pp. 381-83.

Headey, Bruce, Gerhard Hoehne, and Gert G. Wagner. 2014. Does Religion Make You Healthier and Longer Lived? Evidence for Germany. Social Indicators Research 119: 1335-50. [CrossRef]

Hupfeld, Stefan. 2006. Longevity and Redistribution in the German Pension System, Diskussionspapier der Forschergruppe, Heterogene Arbeit: Positive und Normative Aspekte der Qualifikationsstruktur der Arbeit 06/10, Konstanz: Universität Konstanz. Available online: https://kops.uni-konstanz.de/bitstream/handle/123456789/12270/0610.pdf?isAllowed=y\&sequence=1 (accessed on 5 January 2021).

Hupfeld, Stefan. 2009. Rich and Healthy-Better than Poor and Sick? An Empirical Analysis of Income, Health, and the Duration of the Pension Benefit Spell. Journal of Health Economics 28: 427-41. [CrossRef]

Jędrasik-Jankowska, Inetta. 2003. Ubezpieczenie Społeczne. Tom 2. Ubezpieczenie Rentowe, Ubezpieczenie Emerytalne (Social Insurance. Vol 2. Disability and Pension Insurance). Warszawa: LexisNexis.

Jędrasik-Jankowska, Inetta. 2010. Pojęcia i Konstrukcje Prawne Ubezpieczenia Społecznego (Legal Concepts and Structures of Social Insurance). Warszawa: Wolters Kluwer.

Kaplan, George A., Elsie R. Pamuk, John W. Lynch, Richard D. Cohen, and Jennifer L. Balfour. 1996. Inequality in Income and Mortality in the United States: Analysis of Mortality and Potential Pathways. BMJ Clinical Research 312: 999-1002. [CrossRef]

Keeler, Emmett, Jack M. Guralnik, Haijun Tian, Robert B. Wallace, and David B. Reuben. 2010. The Impact of Functional Status on Life Expectancy in Older Persons. Journals of Gerontology Series A: Biomedical Sciences and Medical Sciences 65: 727-32. [CrossRef]

Kinge, Jonas Minet, Jørgen Heibø Modalsli, Simon Øverland, Håkon Kristian Gjessing, Mette Christophersen Tollånes, Ann Kristin Knudsen, Vegard Skirbekk, Bjørn Heine Strand, Siri Eldevik Håberg, and Stein Emil Vollset. 2019. Association of Household Income with Life Expectancy and Cause-Specific Mortality in Norway, 2005-2015. JAMA 321: 1916-23. [CrossRef]

Kluszczyńska, Zofia. 2003. Emerytury i Renty z Funduszu Ubezpieczeń Społecznych (Pensions and Disability Benefits from the Social Insurance Fund). In System Ubezpieczeń Społecznych. Zagadnienia Podstawowe (Social Insurance System. Basic Issues). Edited by Grażyna Szpor. Warszawa: LexisNexis. 
Kreiner, Claus T., Torben H. Nielsen, and Benjamin L. Serena. 2018. Role of Income Mobility for the Measurement of Inequality in Life Expectancy. Proceedings of the National Academy of Sciences 115: 11754-59. [CrossRef] [PubMed]

Lei, Xiaoyan, Yan Shen, James P. Smith, and Guangsu Zhou. 2017. Life Satisfaction in China and Consumption and Income Inequalities. Review of Economics of the Household 16: 76-93. [CrossRef] [PubMed]

Mackenbach, Johan P., José Rubio Valverde, Matthias Bopp, Henrik Brønnum-Hansen, Patrick Deboosere, Ramune Kalediene, Katalin Kovács, Mall Leinsalu, Pekka Martikainen, Gwenn Menvielle, and et al. 2019. Determinants of Inequalities in Life Expectancy: An International Comparative Study of Eight Risk Factors. The Lancet Public Health 4: e529-36. [CrossRef]

Marmot, Michael. 2002. The Influence of Income on Health: Views of an Epidemiologist. Health Affairs 21: 32-44. [CrossRef] [PubMed]

Miceikiene, Astrida, Damian Walczak, and Sylwia Pieńkowska-Kamieniecka. 2019. Social Insurance for Farmers in Poland and Lithuania-A Comparative Analysis. Comparative Economic Research 22: 17-30. [CrossRef]

Nelissen, Jan H. M. 1995. Lifetime Income Redistribution by the Old-Age State Pension in the Netherlands. Journal of Public Economics 58: 429-40. [CrossRef]

Opała, M. 2015. The 443-Year Tree-Ring Chronology for the Scots Pine from Upper Silesia (Poland) as a Dating Tool and Climate Proxy. Geochronometria 42: 41-50. [CrossRef]

Organisation for Economic Co-operation and Development. 2019. Available online: https:/ / data.oecd.org/healthstat/life-expectancyat-birth.htm (accessed on 12 December 2019).

Ostry, Jonathan D., Andrew Berg, and Charalambos G. Tsangarides. 2014. Redistribution, Inequality, and Growth. Washington: International Monetary Fund.

Pope, C. Arden, III, Majid Ezzati, and Douglas W. Dockery. 2009. Fine-Particulate Air Pollution and Life Expectancy in the United States. New England Journal of Medicine 360: 376-84. [CrossRef]

Ross, Catherine E., Ryan K. Masters, and Robert A. Hummer. 2012. Education and the Gender Gaps in Health and Mortality. Demography 49: 1157-60. [CrossRef]

Rysz-Kowalczyk, Barbara, and Barbara Szatur-Jaworska. 2004. Polityka Społeczna Wobec Cyklu Życia. Faza Starości (Social Policy and the Life Cycle. Old Age Phase). In Nasze Starzejące Się Społeczeństwo. Nadzieje i Zagrożenia (Our Aging Society. Hopes and Threats). Edited by Jerzy T. Kowaleski and Piotr Szukalski. Łódź: Wyd, Łódź: Uniwersytetu Łódzkiego.

SII. 2018. Zakład Ubezpieczeń Społecznych w Liczbach (SII by Numbers). Available online: https://www.zus.pl\%E2\%80\% BAdocuments\%E2\%80\%BARaport+roczny+2018.pdf (accessed on 24 November 2019).

SII. 2019. Social Security in Poland, 51. Available online: https://www.zus.pl/documents/10182/167615/Social+Security+in+Poland/ 71ffe1b1-c142-48fa-a67b-0c7e1cec6eb6 (accessed on 14 March 2021).

Solé-Auró, Aida, Domantas Jasilionis, Peng Li, and Anna Oksuzyan. 2018. Do Women in Europe Live Longer and Happier Lives than Men? European Journal of Public Health 28: 847-52. [CrossRef] [PubMed]

Sowiński, Tomasz. 2009. Finanse Ubezpieczeń Emerytalnych (Pension Insurance Finance). Warszawa: Wolters Kluwer.

Steinhilber, Silke. 2004. The Gender Impact of Pension Reforms: Case Studies of the Czech Republic, Hungary, and Poland. In OECD, Reforming Public Pensions: Sharing the Experiences of Transition and OECD Countries. Paris: OECD.

Stiglitz, Joseph E., and Jay K. Rosengard. 2015. Economics of the Public Sector, 4th ed. New York: W.W. Norton \& Company.

Tobiasz-Adamczyk, Beata. 2000. Jakość Życia w Starości-Definicja, Pojęcia (Quality of life in elderly-definition, concepts). In Zrozumieć Starość (Understand Old Age). Edited by Anna Panek and Zofia Szarota. Kraków: Oficyna Wydawnicza TEXT.

Wantoch-Rekowski, Jacek. 2005. Składki na Ubezpieczenie Emerytalne. Konstrukcja i Charakter Prawny (Pension Insurance Contributions. Construction and Legal Nature). Torun: TNOiK. 